\title{
Wastewater Treatment for African Catfish (Clarias gariepinus) Culture by Using Anaerobic Process
}

\author{
D. Darwin*, S. Sarbaini, Satria Purwanto, Fatwa Dhiauddin, Muhammad Ilham, Afrizal Fazil \\ Department of Agricultural Engineering, Syiah Kuala University, Banda Aceh 23111, Indonesia \\ Email: darwin_ae@unsyiah.ac.id
}

Submitted: 21 September 2016; Accepted: 2 Oktober 2017

\begin{abstract}
This study aimed to set up an anaerobic treatment system for the treatment of wastewater derived from the farming of African Catfish (Clarias gariepinus). In this current study, anaerobic treatment of wastewater derived from the African catfish (Clarias gariepinus) aquaculture was conducted in semi-continuous reactor as well as batch reactor under mesophilic condition at $35{ }^{\circ} \mathrm{C}$. The results revealed that the semi-continuous reactors generated higher biogas yield $(69.27 \mathrm{~mL} / \mathrm{g} \mathrm{VS})$ compared with batch reactor $(22.81 \mathrm{~mL} / \mathrm{g} \mathrm{VS})$. High conversion rate of anaerobic treatment process operated in semi-continuous reactor was also represented in higher percentage of COD removal $(82.6 \%)$ compared with batch reactor which was only $62.76 \%$. After conducting anaerobic treatment process on the wastewater derived from the catfish aquaculture, some parameters including total dissolved solids (TDS), Phosphorous (P), potassium (K) and electrical conductivity $(\mathrm{Ec})$ increased in both batch and semi-continuous reactors. Batch reactors showed TS, VS and COD reduced from $0.23 \%, 42.88 \%$ and $1440 \mathrm{mg} / \mathrm{L}$ to $0.137 \pm 0.024 \%, 22.78 \pm 19.44 \%$ and $536.32 \pm 11.27 \mathrm{mg} / \mathrm{L}$, respectively. The results obtained from semi-continuous reactor revealed that TS, VS and COD reduced from $0.23 \%$, $42.88 \%$ and $1440 \mathrm{mg} / \mathrm{L}$ to $0.219 \%, 24.353 \%$ and $250.61 \mathrm{mg} / \mathrm{L}$, respectively. This study is highly significant for the environmental protection system.
\end{abstract}

Keywords: African catfish (Clarias gariepinus); anaerobic treatment; wastewater

\section{INTRODUCTION}

An increasing demand of fish consumption has attracted people worldwide to put a lot of investments in the aquaculture sector. However, the studies by Brown et al. (1999) and Turcios et al. (2014) showed that aquaculture is one of economic activities that may significantly contribute to the pollutions of water as well as soil. Aquaculture systems operated normally generate environmental problems such as untreated wastewater disposal. Wastewater generated from the aquaculture system contains organic compounds including total nitrogen, phosphorus, and suspended solids that may significantly deteriorate water bodies and soil (Brown et al., 1999; Cripps and Bergheim, 2000; Turcios et al., 2014).

Some techniques used by fish producers for increasing fish production including antibiotics and hormones addition, and/or over feeding applied would significantly affect the water quality in the pond. Some studies revealed that the main wastes derived from the aquaculture operations including chemicals and therapeutics, excretion products, uneaten feed and undigested feed residues (Ackefors and Enell, 1994; Beveridge et al., 1991; Pillay and Ramakrishna, 2008). Studies conducted by Ackefors and Enell (1990) and Bergheim et al. (1998) revealed that some forms of waste from the aquaculture activities includes pathogens, dead and dying fish.

Brown et al. (1999) mentioned that some fish normally generate products of nitrogenous waste by doing diffusion and exchanging ion through their urine, feces and gills. Those nitrogenous compounds present in the aquaculture wastewater should be decomposed and reused to prevent the toxicity of ammonia and nitrite. Therefore, it would prevent nitrate to form hypertrophication of the environment. 
An accumulation of solids in an aquaculture system may lead to a slump in water quality. Thus, it would contribute to the stress enhancement of the organisms living in the water. (Rosenthal et al., 1982; Klontz et al., 1985; Cripps and Bergheim, 2000). Organic materials produced from the aquaculture systems could also affect the life of animals and other living organisms in the water. This condition may lead to an increasing of oxygen demand and dissolved oxygen consumption in the water as result of the degradation of solids and organic matters by heterotrophic bacteria (Servais et al., 1999; Welch and Eugene, 2002; Cripps and Bergheim, 2000). If this condition continuously occurs, it would provide an appropriate habitat for the proliferation of pathogenic bacteria (Liltved and Cripps. 1999; Servais et al., 1999; Ackefors and Enell, 1994).

Successful African catfish aquaculture tends to be followed with requiring a proper maintenance of water quality for the growth of fish. Typical water quality problems appeared in the catfish aquaculture include dissolved oxygen (DO), chemical oxygen demand (COD), biological oxygen demand (BOD), total solids (TS), total dissolved solids (TDS), pH, total suspended solids (TSS), volatile solids (VS), total nitrogen (N) and phosphorous (P) (Lyles et al., 2008; Soetardjo et al., 2013). If the wastewater contains high concentration of phosphorous, ammonia and nitrogen, it would disturb the habitat life around the receiving water bodies (Cripps and Bergheim, 2000; Soetardjo et al., 2013).

Anaerobic treatment is considered as an ideal process for treating wastewater. This is because anaerobic digestion process could reduce a significant amount of organic matters including both carbon and nitrogen concentration of liquid and form biogas as the end product (McCarty and Perry, 1964; Darwin et al., 2016; Andel and Breure, 1984). Study conducted by Lier at al. (2008) revealed that anaerobic digestion is regarded as an effective treatment to remove biodegradable organic compounds, leaving mineralized compounds such as $\mathrm{NH}_{4}^{+}, \mathrm{PO}_{4}^{3-}, \mathrm{S}^{2-}$ in the solution.

Some advantages of anaerobic treatment would be well understood when this type of wastewater treatment is compared to the aerobic treatment such as trickling filter and activated sludge processes. In aerobic treatment, the organic matters are used by microorganisms for their food. The oxygen taken from the air is used for burning the food to generate carbon dioxide and water for their energy (McCarty and Perry, 1964). Aerobic treatment process requires a lot of energy leading to a high operational cost. This is because the energy used for running the aeration system is required for pumping the air into the wastewater tank. Lier at al. (2008) mentioned that the oxidation of $1 \mathrm{~kg}$ COD would require about $1 \mathrm{kWh}$ of the aeration energy. They also mentioned that the aerobic treatment of a conventional activated sludge process generates around $50 \%$ new sludge from the COD degraded and required further treatment prior to reusing or discharging. On the other hand anaerobic treatment only generates about $5 \%$ new sludge from the COD converted. This treatment can produce biogas $(60-70 \%)$ as the energy.

In this current study, the anaerobic treatment was conducted for the treatment of wastewater from an intensive channel African catfish wastewater system. The purpose of this study was to investigate and evaluate whether anaerobic treatment using batch as well as semi-continuous reactors could be applied to reduce organic pollutants from the wastewater discharged. Thus, the wastewater treated could be safely discarded, recovered as well as reused to the culture water system. The digestion efficiency and the quality of effluent derived from anaerobic treatment process were evaluated.

\section{MATERIAL AND METHODS}

Aquaculture wastewater used for this experiment was taken from the farming of African catfish at TungkopDarussalam, Aceh Besar District, and this wastewater was stored in the fridge at the temperature of $5^{\circ} \mathrm{C}$ prior to the experiment. No any other inoculums used for this experiment as the anaerobic digestion process operated in this experiment was to treat wastewater directly from the aquaculture of African catfish. The process of anaerobic digestion operated in this experiment depends on the microbial community present in the wastewater, and thereby the acclimatization and performance of anaerobic digestion process would be based on the operational conditions applied.

Operational Systems for the Anaerobic Treatment Process

\section{Batch system}

Batch system was operated in bioreactors with the working volume of $3 \mathrm{~L}$. Each reactor was filled with 3 $\mathrm{L}$ wastewater and placed on the thermostatic water bath computerized respirometer. The temperature for this experiment was maintained under mesophilic condition at $35^{\circ} \mathrm{C}$. The experiments operated in the batch system were carried out at duplicate. Influent and effluent samples were assessed for total phosphorous, potassium, total solids, volatile solids, total dissolved solids, total kjedahl nitrogen based on the "Standard Methods" (APHA, 1998). The duration of this batch tests was determined by the point at which biogas production stopped completely. In this test the experiment was stopped at 15 days of the digestion process. 


\section{Semi-continuous system}

A semi-continuous reactor was operated in steady state condition where the temperature was maintained under mesophilic condition at $\pm 35{ }^{\circ} \mathrm{C}$. The working volume of the reactor was $3 \mathrm{~L}$, and the hydraulic retention time (HRT) applied in the system was 10 days. The organic loading rate applied for this system was $0.098 \mathrm{~kg} / \mathrm{m}^{3}$ day. To ensure the semi-continuous system run properly, $\mathrm{pH}$ of the culture was measured periodically during the feeding period. Biogas production was measured through the water displacement gas meter. Influent as well as effluent samples were analyzed for Phosphorous, potassium, total solids, volatile solids, total dissolved solids, electrical conductivity, salinity, total kjedahl nitrogen based on the "Standard Methods" (APHA, 1998). In order to reach steady state condition the semi-continuous system was operated in 2.5 cycle of the HRT which was 25 days of the digestion process.

\section{Analytical Methods}

Some parameters analyzed for the characterization include total solids (TS), volatile solids (VS), total dissolved solids (TDS), chemical oxygen demand (COD), total kjedahl nitrogen $(\mathrm{TKN}), \mathrm{pH}$, electrical conductivity (EC), salinity, and total concentration of phosphorous (P), and potassium (K). All analytical measurements were carried out based on the "Standard Methods" (APHA, 1998). TS samples were dried in an oven at the temperature of $105^{\circ} \mathrm{C}$, and for VS samples were burnt into a furnace at $550{ }^{\circ} \mathrm{C}$. The rates of biogas production were assessed as the volume of biogas produced per day, and the biogas yield was measured based on the cumulative biogas produced per gram volatile solids added (Liu et al., 2009; Lo et al., 1984; Darwin et al., 2014; Parawira et al., 2008). To analyze the effectiveness of the digestion process, the percent of volatile solids reduction and COD removal was determined based on the formula mentioned and utilized in the some previous studies (Joanne, 1991; Darwin et al., 2014).

$\%$ VS Reduction $=\frac{(\% \text { VS in }-\% \text { VS out })}{\% \text { VS in }-(\% \text { VS in } \times \text { VS out })} \times 100 \%$
$\%$ COD Removal $=\frac{\text { Initial COD }- \text { Final COD }}{\text { Initial COD }} \times 100 \%$

\section{RESULTS AND DISCUSSION}

\section{Batch Reactor Performance}

Results showed that anaerobic digestion was an effective treatment used to treat the aquaculture wastewater derived from the African catfish farming as $\mathrm{pH}$ culture observed was close to the optimum $\mathrm{pH}$ for the anaerobic treatment process (pH 6.5-7.5) (Cheng, 2010; Steinhaus et al., 2007; Burke,
2001). Some parameters including phosphorous, potassium, electrical conductivity and total dissolved solids increased during anaerobic digestion indicating that anaerobic treatment process could degrade complex organic matters into simpler and soluble compounds. Study conducted by Gerardo et al. (2013) also revealed that anaerobic treatment could be used as an effective strategy for the recovery of nutrients from dairy farm sludge which was not readily disposed into nutrients which are ready for the land application. Balasubramanian and Kasturi Bai (1992) and Mehta et al. (2015) also mentioned that anaerobic digestion is an established wastewater treatment technology that could be applied to mineralize complex organic waste into inorganic matter with the formation of biogas as the end-product of the digestion process.

Anaerobic treatment process operated in the batch system was also an effective method to treat the aquaculture wastewater from the African catfish culture. Results revealed that organic matters represented in total solids, volatile solids and chemical oxygen demand are significantly reduced during the anaerobic digestion process. Schmidt (2005) mentioned that some parameter anaerobic digestion including volatile solids and chemical oxygen demand are considered as a measure of the organic matter in the digester that can be converted into biogas. Previous studies conducted by Darwin et al. (2016a) and Darwin et al. (2016b) also found that anaerobic digestion operated in the batch system could effectively reduce organic matters on the culture of swine manure wastewater co-digested with cocoa husk.

Results from this current study also showed that there was a lag phase occurred in the batch reactors for 3 days of the digestion process. This occurred as no inoculum was added to the culture at the beginning of the anaerobic digestion process, and thereby microbes present in the reactors took some times to acclimate to the anaerobic condition prior to converting organic pollutants into biogas. Schultz and Kishony (2013) revealed that a prolonged lag phase would

Table 1. Anaerobic treatment performance operated in batch reactor

\begin{tabular}{lrr}
\hline Parameter & \multicolumn{1}{l}{ Influent } & \multicolumn{1}{l}{ Effluent } \\
\hline $\mathrm{pH}$ & $6.58 \pm 0.014$ & $6.62 \pm 0.480$ \\
Total solids (\%) & $0.23 \pm 0.018$ & $0.137 \pm 0.024$ \\
Volatile solids (\%) & $42.88 \pm 1.396$ & $22.78 \pm 19.44$ \\
TDS (ppm) & $830 \pm 1.414$ & $920 \pm 56.56$ \\
Electrical conductivity (mS) & $1.66 \pm 0.007$ & $1.835 \pm 0.120$ \\
COD (mg/L) & $1440 \pm 25.46$ & $536.32 \pm 11.27$ \\
Phosphorous (mg/L) & $15.5 \pm 0.354$ & $20 \pm 3.535$ \\
Potassium (mg/L) & $52.96 \pm 0.0283$ & $47.73 \pm 30.67$ \\
TKN (mg/L) & $88.31 \pm 0.0071$ & $84.34 \pm 7.00$ \\
\hline
\end{tabular}




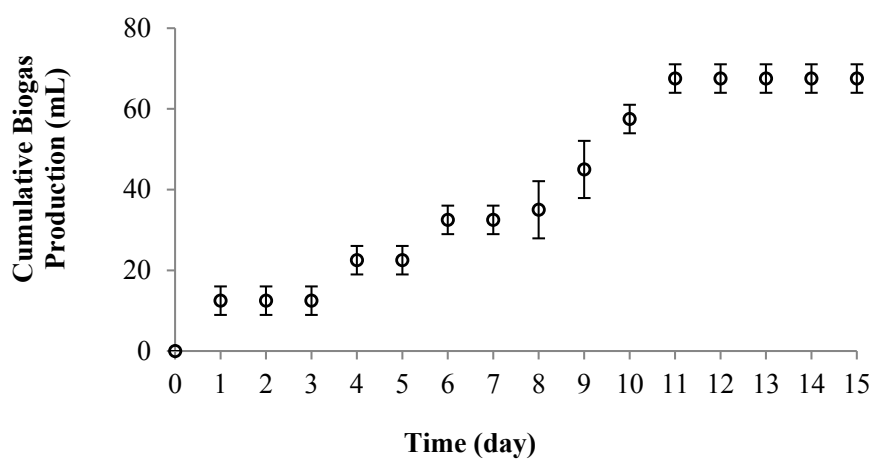

Figure 1. Cumulative biogas production operated in batch reactors

occur when the anaerobic digestion process operated was not added an inoculums as a starter. These results also confirmed that anaerobic digestion of aquaculture wastewater could be performed without adding inoculums, and could reduce the time and cost for enriching anaerobic inocula and/or purchasing a starter.

\section{Semi-Continuous Reactor Performance}

Results from the previous tests showed that anaerobic treatment operated in the batch reactors could successfully reduce organic materials and converted it into biogas as a byproduct. Since in the real world application, the aquaculture wastewater generated from the African catfish farming is a lot and continuously discarded, to prevent an excessive amount of untreated wastewater disposed, semi-continuous operation was applied. Results showed that $\mathrm{pH}$ culture slightly increased from 6.58 to 6.90. Labatut and Gooch (2012) revealed that in a well-operated anaerobic treatment, a slight increase of $\mathrm{pH}$ in the effluent is expected. This condition occurred by the alkalinity which produced by microorganisms, while they consume organic matter containing any considerable amount of protein. Overall the semi-continuous reactor performed sufficiently well during the anaerobic treatment process in which $\mathrm{pH}$ culture was quite stable, so could successfully convert organic matters into biogas.

The formation of biogas during the anaerobic treatment process also indicated that the digestion process performed properly for degrading organic matters of wastewater (Figure 2). Studies conducted by Kader et al. (2015) and Klinkner (2014) revealed that anaerobic digestion process of organic wastes would be completed by converting organic matters into biogas containing about $50-70 \%$ methane and small amount of $\mathrm{CO}_{2}$ and $\mathrm{H}_{2} \mathrm{~S}$. The formation of biogas indicated that the anaerobic treatment have completed each stage of anaerobic digestion including acidogenesis, acetogenesis and methanogenesis (Appels et al., 2008).

Methanogenesis is the last phase of the anaerobic digestion which is very sensitive to the acidic and/or alkaline
Table 2. Anaerobic treatment performance operated in semicontinuous reactor

\begin{tabular}{lll}
\hline Parameter & Influent & Effluent \\
\hline $\mathrm{pH}$ & $6.58 \pm 0.014$ & $6.90 \pm 0.017$ \\
Total solids (\%) & $0.230 \pm 0.018$ & $0.219 \pm 0.104$ \\
Volatile solids (\%) & $42.88 \pm 1.396$ & $24.353 \pm 2.099$ \\
TDS (mg/L) & $830 \pm 1.414$ & $900 \pm 5.774$ \\
Electrical conductivity (mS) & $1.66 \pm 0.007$ & $1.79 \pm 0.006$ \\
COD (mg/L) & $1440 \pm 25.46$ & $250.61 \pm 0.361$ \\
Phosphorous (mg/L) & $15.5 \pm 0.354$ & $26.25 \pm 0.0353$ \\
Potassium (mg/L) & $52.96 \pm 0.0283$ & $66.11 \pm 0.004$ \\
TKN (mg/L) & $88.31 \pm 0.0071$ & $90 \pm 1.195$ \\
\hline
\end{tabular}

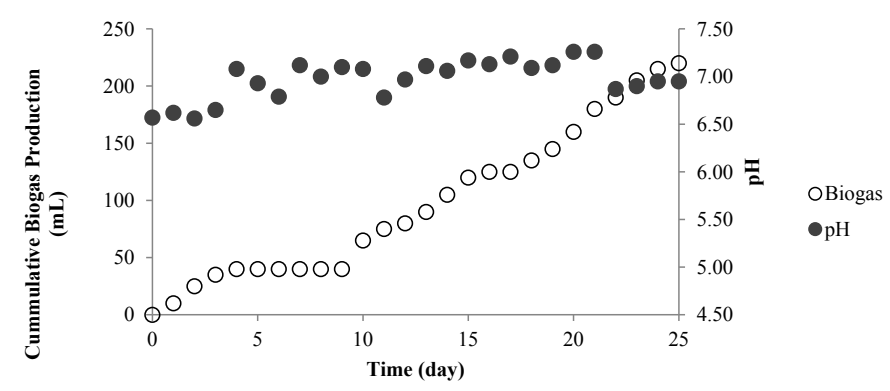

Figure 2. Cumulative biogas production and $\mathrm{pH}$ in semi-continuous reactor

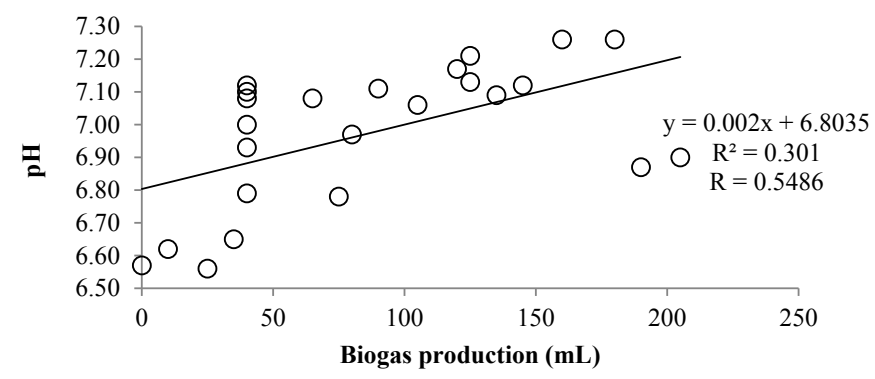

Figure 3. Correlation between $\mathrm{pH}$ and Biogas production

conditions (Appels et al., 2011). Khalid et al. 2011) and Esposito et al. (2012) mentioned that maintaining $\mathrm{pH}$ culture in the appropriate level $(6.5-7.5)$ is essential to complete the anaerobic digestion of organic waste to form biogas. Results showed that $\mathrm{pH}$ culture in the semi-continuous reactor was stable in the range of the optimum $\mathrm{pH}$ for anaerobic digestion (Figure 2). In this test, $\mathrm{pH}$ contributed to a $30 \%$ of biogas production as a result of a complete anaerobic treatment of African catfish wastewater (Figure 3). This phenomenon indicated that during anaerobic treatment of catfish wastewater, organic matter reduction to form biogas was also influenced by other factors as revealed in Table 2 .

Results showed that during the anaerobic treatment process of aquaculture wastewater, there was a slight increase of total dissolved solid (TDS). TDS increased from $830 \mathrm{mg} / \mathrm{L}$ (influent) to $900 \mathrm{mg} / \mathrm{L}$ in effluent (Figure 4). This result is in 
agreement with the previous study conducted by Jayakody et al. (2007) revealing that an increasing of TDS over the time in anaerobic reactor could be attributed to the product of the biochemical conversion during anaerobic digestion. Furthermore, study revealed that TDS in the wastewater typically consists of some chemical contaminants including calcium, chlorides, nitrate, phosphorus, sodium, potassium iron and sulfur (EPA, 2014a). TDS is also regarded as an expected product during the anaerobic digestion process that would be required as a substrate for further stages of anaerobic digestion process including acidogenesis as well as methanogenesis. Jayakody et al. (2007) revealed that an increasing of TDS during anaerobic digestion could indicate that acidogenic products such as organic acids including volatile fatty acids (VFA) and alcohols were formed.

\section{Effect semi-continuous anaerobic treatment process on water quality of the effluent}

Results showed that there was any correlation between TDS concentration and biogas production (Figure 5). The correlation of TDS and biogas production generates the $\mathrm{R}$-square of 0.68 . This result indicated that during the anaerobic treatment process of wastewater, TDS give a significant contribution of $68.7 \%$ for the formation of biogas, and could reduce organic as well as inorganic materials present in the aquaculture wastewater. Results also revealed that there was a strong relationship between electrical conductivity (EC) and biogas production during anaerobic treatment of African catfish wastewater in which the coefficient correlation of this relationship was 0.8 (Figure 6). This phenomenon indicated that during the anaerobic treatment of African catfish wastewater, the performance of anaerobic digestion process was highly affected by the EC of the culture.

High EC in the wastewater indicated that there were some inorganic dissolved solids represented as inorganic ions present in the wastewater including anions (ions that carry a negative charge) as well as cations (ions that carry a positive charge). The anions of inorganic ionic solutes present in the wastewater include chloride $(\mathrm{Cl})$, nitrate $\left(\mathrm{NO}_{3}^{-}\right)$, sulfate $\left(\mathrm{SO}_{4}{ }^{2-}\right.$ ), bicarbonate $\left(\mathrm{HCO}_{3}^{-}\right)$and phosphate $\left(\mathrm{PO}_{4}^{3-}\right)$; and the cations of inorganic ions available are sodium $\left(\mathrm{Na}^{+}\right)$, potassium $\left(\mathrm{K}^{+}\right)$, magnesium $\left(\mathrm{Mg}^{2+}\right)$, calcium $\left(\mathrm{Ca}^{2+}\right)$, iron $\left(\mathrm{Fe}^{2+}\right)$, and aluminum $\left(\mathrm{Al}^{3+}\right)$. Those inorganic ions could significantly affect EC in the wastewater. However, some components derived from organic compounds such sugar, protein, oil, alcohol and phenol would not affect EC (EPA, 2014b; Uwidia and Ukulu, 2013).

Some inorganic ionic solutes present in the wastewater were required for providing buffer capacity in the anaerobic digester. Lin and Lay (2004) reported that some inorganic ions required for enhancing buffer capacity in the anaerobic

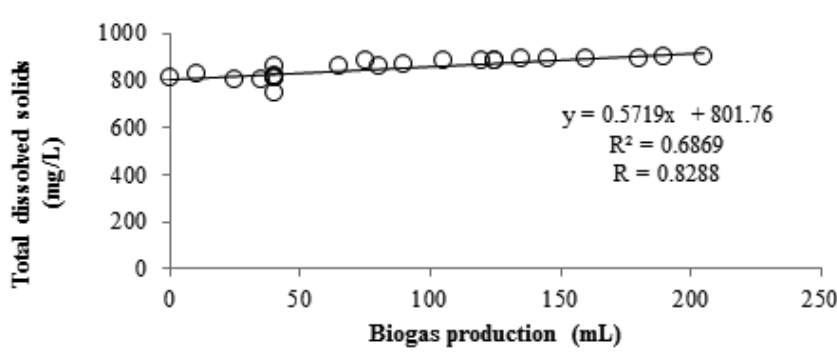

Figure 5. Correlation between total dissolved solids and biogas production

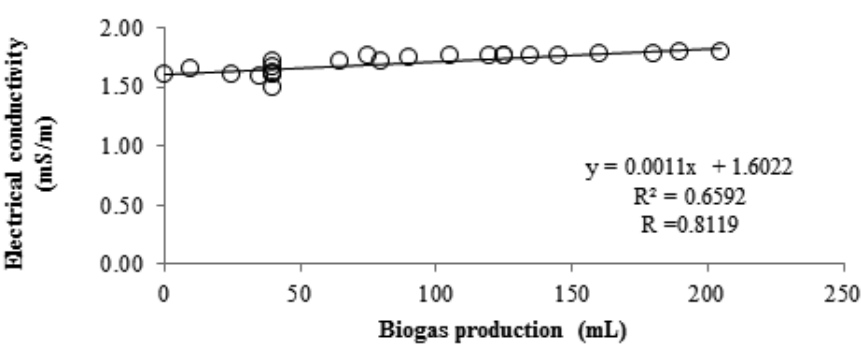

Figure 6. Correlation between electrical conductivity and biogas production

digester included phosphate and carbonate. However, high concentration of carbonate was not favorable during anaerobic digestion since it could reduce the production of biogas by forming carbon dioxide. The presence of some inorganic ions such as sodium $\left(\mathrm{Na}^{+}\right)$, potassium $\left(\mathrm{K}^{+}\right)$, magnesium $\left(\mathrm{Mg}^{2+}\right)$, calcium $\left(\mathrm{Ca}^{2+}\right)$ would enhance the performance of anaerobic treatment of the wastewater, and increase the biogas production. Chen et al. (2007) showed that the combination of these ions in the digester could limit the accumulation of ammonia in the digester. Results from this current study also revealed that the presence of some inorganic ionic solutes represented in high values of EC in the culture would have a significant impact on the anaerobic treatment to complete the digestion process by reducing organic materials present in the wastewater

Results showed that during anaerobic treatment process of African catfish aquaculture wastewater, an increasing of TDS concentration over the period of time was followed by an increasing level of EC values in the digester (Figure 7). An increasing of TDS followed by an increase of EC during the anaerobic treatment of catfish wastewater showed that there was a process of converting complex organic compounds into soluble constituents (Lier et al., 2008; Uwidia and Ukulu, 2013). Lier et al. (2008) mentioned that there was a process of mineralizing soluble compounds into inorganic ionic solutes during the anaerobic digestion process.

The positive linear relationship between TDS concentration and EC during the anaerobic treatment process of African catfish wastewater was also followed by the positive correlation to the level of salinity of the culture (Figure 8 and 9). Results showed that salinity concentration had a strong 


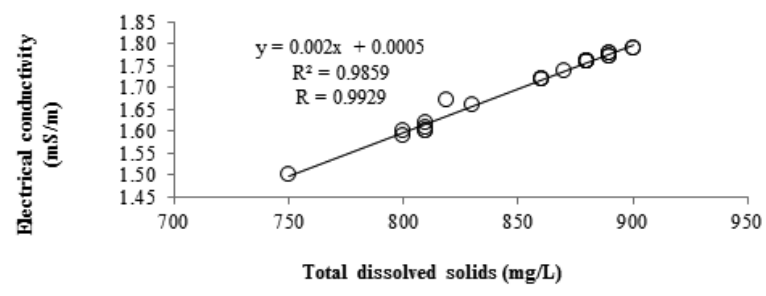

Figure 7. Linear regression of electrical conductivity and total dissolved solids

relationship with both EC and TDS concentration. This is due to the fact that salinity of the wastewater obtained from the African catfish aquaculture was related to some inorganic constituents, which also determined the level of EC and TDS concentration in the wastewater. Lantzke et al. (2007) and Kumar and Puri (2012) mentioned that some inorganic compounds as well as constituents that affect the level of salinity concentration in the wastewater include chlorides, sulfate, calcium and magnesium bicarbonates and common salt or sodium chloride.

Salinity, TDS and EC are parameters that should be monitored for water quality assessment of the treated wastewater. This is because those parameters were considered as a critical factor that affect the worthwhile reuse of effluent for plant irrigation, and could give a significant impact on the quality of fresh water streams (Tjandraatmadja and Diaper, 2006). Some studied conducted by Gupta and Huang (2014) and Abdallah et al. (2016) revealed that irrigation water containing high level of salinity could affect the plant growth in some ways including the toxic effect and salinity effect. The toxic effect was caused by high concentration of sodium and chloride ion. High salinity of irrigation water should also be prevented as the plant that contaminated with high saline irrigation water had to work much harder to absorb water from the soil, and thereby could lower the plant growth and lead to cut the crop yields (Lantzke et al., 2007).

Even if there was an increase of concentration in terms of salinity, TDS and EC during the period of time of anaerobic treatment process, it would not affect the performance of the anaerobic treatment process to reduce organic pollutants. During anaerobic treatment process of African catfish aquaculture wastewater, a slight increase of salinity, TDS and EC over the period of time. It indicated that there was a process of mineralization that occurs in anaerobic treatment of wastewater in which the inorganic ionic solutes generated was as a result of biochemical conversion. In addition, an increase concentration of those parameters would not significantly affect the effluent derived from anaerobic treatment process to be unsafe for disposal. A low concentration of inorganic constituents was also required for enhancing buffer capacity during anaerobic treatment in order

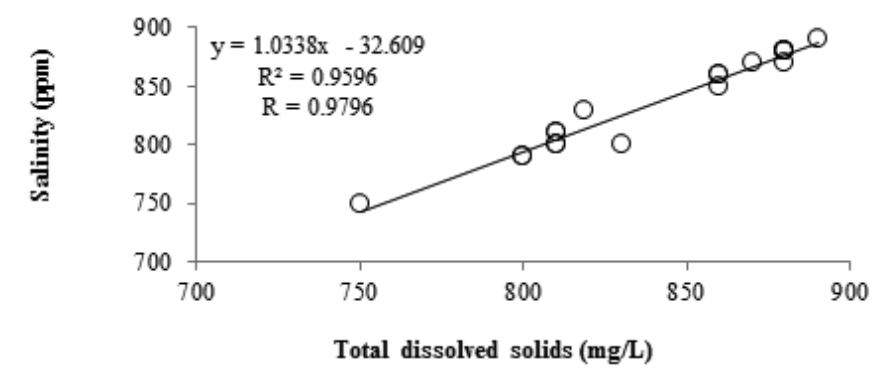

Figure 8 . Linear regression of total dissolved solids and salinity

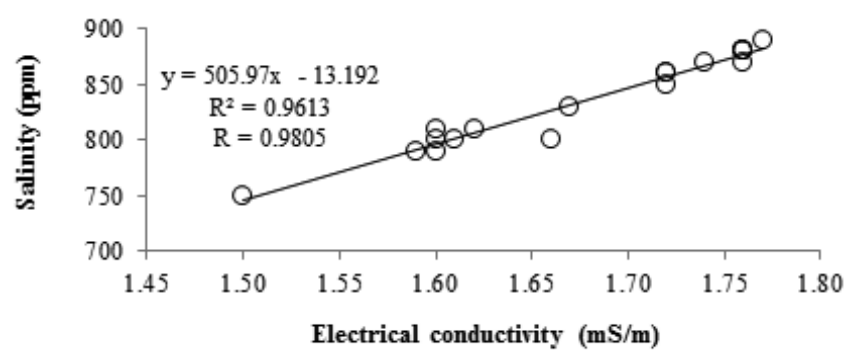

Figure 9. Linear regression of salinity and electrical conductivity

to avoid an accumulation of ammonia that could lower as well as inhibit the performance of anaerobic treatment process. Results showed that the effluent of wastewater that had been treated through anaerobic treatment process was safe enough for disposal as TDS and salinity and EC were still lower than the concentration that was restricted for discharging (Lantzke et al., 2007).

\section{Efficiency of Biodegradation}

Studies revealed that the digestibility as well as components of wastewater is regarded as one of some parameters in anaerobic treatment process that may significantly determine the quantity of biogas generated (Wilkie, 2005; Darwin et al., 2016). Table 3 summarizes anaerobic treatment process efficiency operated at semicontinuous reactors as well as batch reactors. As can be seen, semi-continuous reactors had higher biogas yield (69.27 mL/g VS) compared with batch reactors, which was only $22.81 \mathrm{~mL} / \mathrm{g}$ VS. High conversion rate of anaerobic treatment process run at semi-continuous reactors was also represented in higher percentage of COD removal $(82.6 \%)$ compared with batch reactor which was only $62.76 \%$. The COD removal achieved in this study was quite well in which some studies (Can et al., 2006; Göblös et al., 2008) revealed that an effective anaerobic wastewater treatment could reach $\geq 80 \%$ of COD removal.

Even if volatile solids reduction of semi-continuous reactor was lower than batch reactor, the semi-continuous reactor still performed sufficiently well by accomplishing COD removal. Then, the total biogas production and biogas 
yield higher than batch reactor. Based on the experimental results, in overall, both semi-continuous reactor and batch reactors performed satisfactorily for treating the aquaculture wastewater derived from the African catfish farm as both system could significantly reduce organic contents in the wastewater.

Table 3. Efficiency of digestion

\begin{tabular}{lcc}
\hline \multicolumn{1}{c}{ Parameter } & $\begin{array}{c}\text { Semi-continuous } \\
\text { reactor }\end{array}$ & $\begin{array}{c}\text { Batch } \\
\text { reactor }\end{array}$ \\
\hline Total biogas production $(\mathrm{mL})$ & 205 & 67.5 \\
Biogas yield (mL/g VS) & 69.27 & 22.81 \\
Volatile solids reduction (\%) & 57.13 & 60.66 \\
COD removal (\%) & 82.6 & 62.76 \\
\hline
\end{tabular}

\section{CONCLUSIONS}

Anaerobic treatment process on the aquaculture wastewater derived from the farming of African catfish, operated in both batch and semi-continuous reactors performed sufficiently well. The two types of anaerobic treatment applied could significantly reduce some organic materials in the wastewater. Semi-continuous reactor performed better compared with batch reactors in terms of the COD removal and biogas yield. Semi-continuous reactor would be more preferable and effective used to treat wastewater from the African catfish farm as it could accommodate a lot of aquaculture wastewater that was continuously discharged.

\section{ACKNOWLEDGMENTS}

The authors would like to record their thanks to Institute for Research and Community Services, Syiah Kuala University for partly funding this research work.

\section{REFERENCES}

Abdallah, S.B., Aung, B., Amyot, L., Lalin, I., Lachâal, M., Karray-Bouraoui, N. and Hannoufa, A. (2016). Salt stress $(\mathrm{NaCl})$ affects plant growth and branch pathways of carotenoid and flavonoid biosyntheses in Solanum nigrum. Acta physiologiae plantarum 38(3): 72.

Ackefors, H. and Enell, M. (1994). The release of nutrients and organic matter from aquaculture systems in Nordic countries. Journal of Applied Ichthyology 10(4): 225241.

Ackefors, Hans and Enell, M. (1990). Discharge of nutrients from Swedish fish farming to adjacent sea areas. Ambio 19: $28-35$.
Andel, V.J.G. and Breure, A.M. (1984). Anaerobic waste water treatment. Trends in Biotechnology 2(1): 16-20.

Appels, L., Baeyens, J., Degrève, J. and Dewil, R. (2008). Principles and potential of the anaerobic digestion of waste-activated sludge. Progress in energy and combustion science 34(6): 755-781.

Apspel, L., Lauwers, J., Degrève, J., Helsen, L., Lievens, B., Willems, K. and Dewil, R. (2011). Anaerobic digestion in global bio-energy production: potential and research challenges. Renewable and Sustainable Energy Reviews 15(9): 4295-4301.

APHA. (1998). Standard Methods for the Examination of Water and Wastewater. American Public Health Association (APHA), American Water Works Association, Water Environment Federation, Washington, D.C.

Balasubramanian, P.R. and Bai, R.K. (1992). Evaluation of nutrient recovery after anaerobic digestion of cattle dung in a family size biogas plant. Biomass and Bioenergy 3(5): 377-380.

Bergheim, A., Cripps, S.J. dan Liltved, H. (1998). A system for the treatment of sludge from land-based fish-farms. Aquat. Liv. Res. 11, 279-287.

Beveridge, M.C.M., Phillips, M.J. and Clarke, R.M. (1991). A quantitative and qualitative assessment of wastes from aquatic animal production. Aquaculture and Water Quality. Advances in World Aquaculture 3: 506-533.

Brown, J.J. Glenn, E.P. Fitzsimmons, K.M. Smith, S.E. (1999). Halophytes for the treatment of saline aquaculture effluent. Aquaculture 175: 255-268.

Burke, D.A. (2001). Dairy Waste Anaerobic Digestion Handbook Options for Recovering Beneficial Products from Dairy Manure. Environmental Energy Company. Olympia, WA.

Can, O.T., Kobya, M., Demirbas, E. and Bayramoglu, M. (2006). Treatment of the textile wastewater by combined electrocoagulation. Chemosphere 62(2): 181-187.

Cheng, J. (2010). Biomass to Renewable Energy Process. CRC Press. USA.

Chen, Y., Cheng, J.J. and Creamer, K.S. (2008). Inhibition of anaerobic digestion process: a review. Bioresource Technology 99(10): 4044-4064.

Cripps, S.J. and Bergheim, A. (2000). Solids management and removal for intensive land-based aquaculture production systems. Aquacultural Engineering 22: 33-56. 
Darwin, Cheng, J.J., Liu, Z. and Gontuphil, J. (2016a). Anaerobic co-digestion of cocoa husk with digested swine manure: evaluation of biodegradation efficiency in methane productivity. Agricultural Engineering International: The CIGR Journal 18(4): 147-156.

Darwin, Cheng, J.J., Gontupil, J. and Liu, Z. (2016b). Influence of total solid concentration for methane production of cocoa husk co-digested with digested swine manure. International Journal of Environment and Waste Management 17(1): 71-90.

Darwin, Cheng J.J., Liu, Z., Gontupil, J. and Kwon, O.S. (2014). Anaerobic co-digestion of rice straw and digested swine manure with different total solid concentration for methane production. International Journal of Agricultural and Biological Engineering 7(6): 79-90.

EPA. (2014a). Total Solids: What are total solids and why are they important? U.S. Environmental Protection Agency. Washington, DC, USA.

EPA. (2014b). Conductivity: What is conductivity and why is it important?.U.S. Environmental Protection Agency. Washington, DC, USA.

EPA. (1996). Environmental indicators of water quality in the United States. U.S. Environmental Protection Agency. Washington, DC, USA.

Esposito, G., Frunzo, L., Giordano, A., Liotta, F., Panico, A. and Pirozzi, F. (2012). Anaerobic co-digestion of organic wastes. Reviews in Environmental Science and Bio/Technology 11(4): 325-341.

Gerardo, M.L., Zacharof, M.P. and Lovitt, R.W. (2013). Strategies for the recovery of nutrients and metals from anaerobically digested dairy farm sludge using crossflow microfiltration. Water research 47(14): 4833-4842.

Göblös, S., Portörő, P., Bordás, D., Kálmán, M. and Kiss, I. (2008). Comparison of the effectivities of twophase and single-phase anaerobic sequencing batch reactors during dairy wastewater treatment. Renewable Energy 33(5): 960-965.

Gupta, B. and Huang, B. (2014). Mechanism of salinity tolerance in plants: physiological, biochemical, and molecular characterization. International Journal of Genomics 2014(3): 1-18.

Jayakody, K.P.K., Menikpura, S.N.M., Basnayake, B.F.A. and Weerasekara, R. (2007). Development and evaluation of hydrolytic/acidogenic first stage anaerobic reactor for treating municipal solid waste in developing countries. Proceedings of international conference on sustainable solid waste management, Chennai, India: 363-369.
Joanne, K.P. (1991). Applied Math for Wastewater Plant Operators. CRC Press. New York, USA.

Kader, F., Baky, A.H., Khan, M.N.H. and Chowdhury, H.A. (2015). Production of biogas by anaerobic digestion of food waste and process simulation. American Journal of Mechanical Engineering 3(3): 79-83.

Khalid, A., Arshad, M., Anjum, M., Mahmood, T. and Dawson, L. (2011). The anaerobic digestion of solid organic waste. Waste Management 31(8): 1737-1744.

Klinkner, B.A. (2014). Anaerobic digestion as a renewable energy source and waste management technology: What must be done for this technology to realize success in the United States. UMass Law Review 9: 68-179.

Klontz, G.W., Stewart, B.C. and Eib, D.W. (1985). On the etiology and pathophysiology of environmental gill disease in juvenile salmonids. Fish and Shellfish Pathology. Academic Press, London.

Kumar, M. and Puri, A. (2012). A review of permissible limits of drinking water. Indian journal of Occupational and Environmental Medicine 16(1): 40.

Labatut, R.A. and Gooch, C.A. (2012). Monitoring of Anaerobic Digestion Process to Optimize Performance and Prevent System Failure. Department of Biological and Environmental Engineering, Cornell University, Ithaca. New York.

Lantzke, N., Calder, T., Burt, J. and Prince, R. (2007). Water Salinity and Plant Irrigation. Department of Agriculture and Food, Government of Western Australia, South Perth WA.

Lin, C.Y. and Lay, C.H. (2004). Effects of carbonate and phosphate concentrations on hydrogen production using anaerobic sewage sludge microflora. International Journal of Hydrogen Energy 29(3): 275-281.

Lier, V., Jules, B., Mahmoud, N. and Zeeman, G. (2008). Anaerobic wastewater treatment: biological wastewater treatment, principles, modelling and design. IWA Publishing. London, UK.

Liltved, H. and Cripps, S.J. (1999). Removal of particle associated bacteria by prefiltration and ultraviolet irradiation. Aquaculture Research 30(6): 445-450.

Liu, Zhang, R., El-Mashad, H.M. and Dong, R. (2009). Effect of feed to inoculum ratios on biogas yields of food and green wastes. Bioresource Technology 100(21): 5103 5108.

Lo, K.V., Liao, P.H., Bulley, N.R. and Chieng, S.T. (1984). A comparison of biogas production from dairy manure 
filtrate using conventional and fixed film reactors. Canadian Agricultural Engineering 26(1): 73-78.

Lyles, C., Boopathy, R., Fontenot, Q. and Kilgen, M. (2008). Biological treatment of shrimp aquaculture wastewater using a sequencing batch reactor. Applied Biochemistry and Biotechnology 151(2-3): 474-479.

McCarty, P.L. (1964). Anaerobic waste treatment fundamentals. Public Works 95(9): 107-112.

Mehta, C.M., Khunjar, W.O., Nguyen, V., Tait, S. and Batstone, D.J. (2015). Technologies to recover nutrients from waste streams: a critical review. Critical Reviews in Environmental Science and Technology 45(4): 385427.

Parawira, W., Read, J.S., Mattiasson, B. and Bjornsson, L. (2008). Energy production from agricultural residues: high methane yields in pilot-scale two-stage anaerobic digestion. Biomass and Bioenergy 32: 44-50.

Pillay, T.V.R. (2008). Aquaculture and the Environment: John Wiley and Sons.

Rosenthal, H., Hoffmann, R., Jörgensen, L., Krüner, G., Peters, G., Schlotfeldt, H.J. and Schomann, H. (1982). Water management in circular tanks of a commercial intensive culture unit and its effects on water quality and fish condition. International Council for the Exploration of the Sea (ICES) Statutory meeting, C.M. 1982/F:22, 13.

Schmidt (2005). Anaerobic digestion Overview. University of Minnesota - Extension, Department of Biosystem and Agricultural Engineering. Minnesota. USA.

Schultz, D. and Kishony, R. (2013). Optimization and control in bacterial Lag phase. BMC Biology 11(1): 120.
Servais, P., Garnier, J., Demarteau, N., Brion, N. and Billen, G. (1999). Supply of organic matter and bacteria to aquatic ecosystems through waste water effluents. Water Research 33(16): 3521-3531.

Soetardjo, S., Tasnim, M.Y., Thanabalan, P. and Noor, A.M. (2013). Sustainability and green treatment of aquaculture wastewater: effect of media used in nonvegetated constructed wetland for removal of cod and total solid from wastewater of catfish tank. Science International 25(4): 791-795.

Steinhaus, B., Garcia, M.L., Shen, A.Q. and Angenent, L.T. (2007). A portable anaerobic microbioreactor reveals optimum growth conditions for the methanogen Methanosaeta concilii. Applied and Environmental Microbiology 73(5): 1653-1658.

Tjandraatmadja, G. and Diaper, C. (2006). Sources of critical contaminants in domestic wastewater - a literature review. CSIRO: Water for a Healthy Country National Research Flagship.

Turcios, A.E. and Papenbrock, J. (2014). Sustainable treatment of aquaculture effluents - what can we learn from the past for the future? Sustainability 6(2): 836-856.

Uwidia, I.E. and Ukulu, H.S. (2013). Studies on electrical conductivity and total dissolved solids concentration in raw domestic wastewater obtained from an estate in Warri, Nigeria. Greener Journal of Physical Sciences 3(3): 110-114.

Welch, E.B. (2002). Ecological Effects of Waste Water: Applied Limnology and Pollutant Effects: CRC Press.

Wilkie, A.C. (2005). Anaerobic digestion of dairy manure: Design and process consideration. natural resource. Agriculture, and Engineering Service 176: 301-312. 